JOHN MINTO is president of the Palestine Solidarity Network Aotearoa (PSNA).

\section{Lively account of Middle East conflict}

\section{Dances With Death - Perilous Encounters Reporting on Hostilities in the Turbulent Middle East, by Tuma Hazou. Auckland, NZ: Tuma Hazou. 2020, 148 pages. ISBN 9780473506056}

$\mathrm{D}$ ANCES with Death is an extraordinary personal account of Palestinian journalist Tuma Hazou's experiences in a 40-year journalism career mostly spent reporting from the warravaged Middle East.

As a young Palestinian, Tuma accepted a job with the BBC in London and became their youngest announcer at just 22. After a decade he transferred to Jordan and in subsequent years was at the heart of reporting on events in the Middle East.

Tuma traces the Middle East conflict to the infamous Balfour Declaration whereby in 1917, in a single sentence, the British government expressed support for the establishment of a Jewish homeland in Palestine. He quotes the second part of the sentence in the declaration, which is almost always overlooked:

...it being clearly understood that nothing shall be done which may

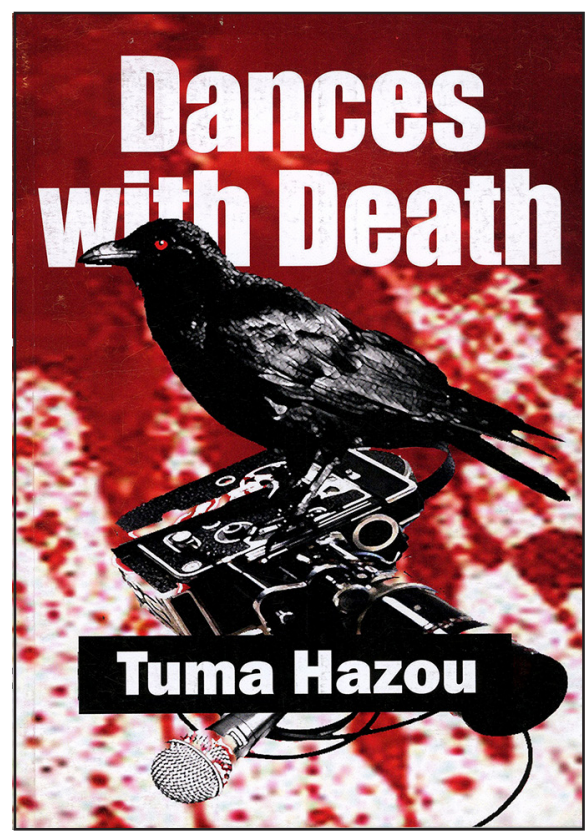

prejudice the civil and religious rights of existing non-Jewish communities in Palestine or the rights and political status enjoyed by Jews in any other country.

Needless to say the Israeli leadership and their fanatical militias ignored this second part of the sentence and in 1948 ethnically cleansed between 750,000 and one million Palestinians from their homes and land in Palestine and to this day refuse to allow them to return. Against the background of this monumental injustice (referred to as the Naqba - catastrophe - by Pales tinians), the Middle East conflict has raged, smouldered and raged ever since.

Parts of the book read like a James Bond thriller, such as the bullet that went through the back windscreen, past Tuma and a colleague, and out 
through the front windscreen as the car they were in careered away. Air attacks from Israeli Skyhawks in Jordan are vividly described and the terror Tuma and others felt as they scrambled for their lives time and time again.

Throughout the book Tuma recalls his encounters with ordinary people who were the victims of Israeli brutality as well as with many higher profile players in the drama. These include his meeting with Jordan's King Hussein atop a captured Israeli tank in 1968 and his encounters with the courageous and feisty British Labour MP Margaret McKay who fought to have the truth about the Naqba reported around the world.

Several addenda to the book add to the understanding of the conflict, in particular the 1978 US position on the legality of Israeli settlements and a piece from Robert Fisk. Dances with Death is a unique, lively, first-hand account of the Middle East conflict told with warmth, compassion and a deep humanity. Tuma and his family live in Auckland, New Zealand.
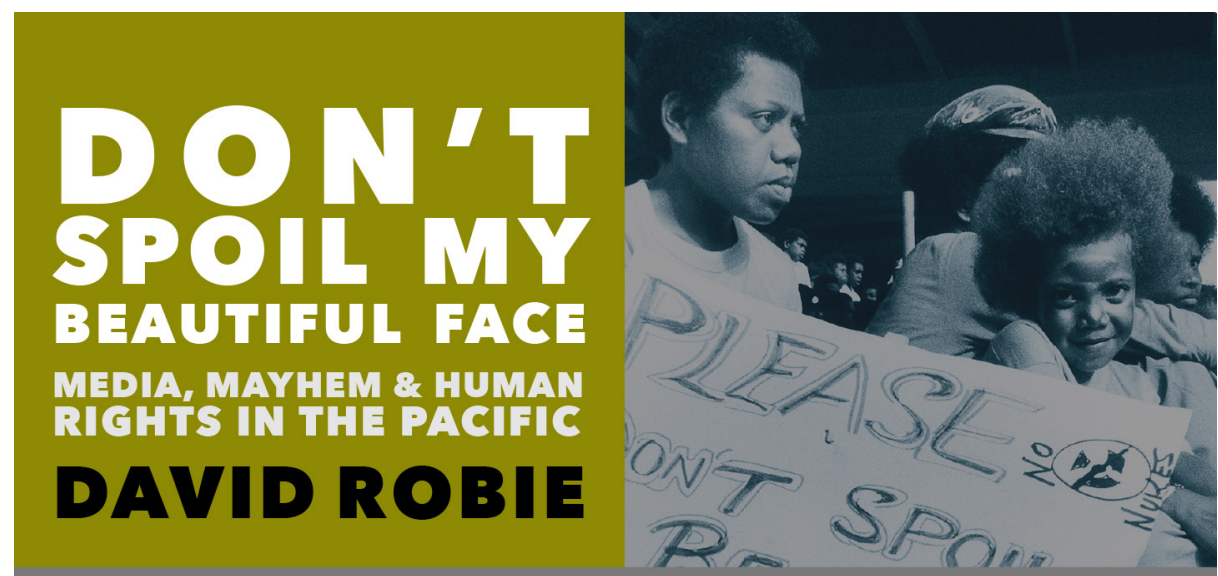

"This is an extraordinary 'secret history' of a vast region of the world of which David Robie has been a rare expert witness. What makes this epic work so timely is that it allows us to understand the Asia-Pacific at a time of renewed cold war ambitions and dangers." - John Pilger

little island press • ISBN 978-1-877484-25-4 • www.littleisland.co.nz 